Tatjana Devjak, Darja Zorc Maver

\title{
Child Rights and Preventive Educational Activities in Public Elementary Schools in Response to Violence and Deviant Behaviour
}

\begin{abstract}
Keywords: child rights, educational concept, public school, deviant behaviour, preventive activities
\end{abstract}

DOI: $10.4312 /$ ars.12.1.124-138

\section{Introduction}

As early as in 1991, Zgaga determined that, in fact, nobody - teachers, the state, or pupils - was satisfied with the Slovenian school system. Over the years, schools have aimed to help children obtain knowledge and form good personalities, as well as replace parents in some respects and at certain times. We require order and discipline at school, while at the same time we want the system to be kinder to children, and often accuse it of manipulating young people (Milharčič, 1994). Schools should also not be guided by any ideology, and thus public schools should not impose on their pupils any beliefs and values that are not commonly agreed on. At the same time, there must be an open space for different people, their beliefs and values; because today's society is a pluralistic one, and a public school must be a safe space for all. Society has changed dramatically in recent decades, and these changes affect the life and work of a school, the development of individuals, the relationships between teachers and pupils, among the pupils themselves. However, it is precisely this complexity of factors that contributes to the deviant behaviour of individuals in school. Therefore, the purpose of this paper is to illustrate the importance of the educational concepts that are applied in a public school, as reflected in the realisation of a value system derived from human and child rights, and to analyse the factors that influence inadequate and aggressive behaviour. The importance of preventive educational activity is also shown in this paper, and a school cannot merely stifle deviant behaviour, but must also influence pupils' understanding of the meaning of action, which does not exclude, deprive, or disable the safe and successful coexistence of pupils. 


\section{Human and child rights as the basis of the educational concept in today's public schools: public school as the carrier of education, its tasks and problems}

Compulsory public school as a state institution was not created overnight, but can be linked to the emergence of a written culture, with schools created and preserved as an effect of the use of writing (Počkar, 1997). Literacy first appeared as a project of religious reform; only in the second half of the $18^{\text {th }}$ century did the state emerge as the bearer of mass literacy with the introduction of compulsory elementary education. The establishment of compulsory, public, state schools as institutions lasted until the end of the $19^{\text {th }}$ century. Today, school, as a public, state matter and compulsory activity on the one hand, and as a right of individuals on the other, is considered as a key institution of a modern society. For example, (il)literacy, the length of compulsory schooling, the number of people involved in schooling at individual levels, and so on, are all indicators of development or the lack thereof of a country (Devjak, 2017).

A public school is an educational institution accessible to all people on the same terms, and enables pupils to carry out the organised and systematic acquisition of knowledge. Such a school is publicly conceived and sanctioned by state law, and cannot be influenced by the Church. We connect the concept of the public with the social community, with its interests, affairs, tasks, and roles. The term 'public' here means what is intended for the use and benefit of all people, and represents a cultural and civilizational benefit. The educational concept of Slovenian preschool institutions and elementary schools is based on human and child rights, the key characteristic of which is consensual values (acceptable for almost everybody). Child rights are based on three concepts, or, in current terms, on three pillars: on the protection, provision, and participation of empowered children (Pavlovič, 2000). The first concept, called the 'concept of protection'1 of the child, specifies criteria for protecting children from neglect and abuse. The most important guiding principle here is the child's benefit. The second concept, called the 'concept of provision', covers all children's rights to have, receive, and access certain things and services. The third concept, called the 'concept of participation' of a pupil in the educational environment, enables the pupil to personally grow, increase their responsibility, and search for their own individuality and identity. In this the key term is empowerment (Zaviršek, 1997; Pavlovič, 2000), when an individual strengthens his or her power to control his or her life.

1 We are not thinking here primarily about so-called physical protection, but to protect against all kinds of neglect and exploitation, before actions or habits that promote racial, religious or any other form of discrimination. 
We know that even the most liberal schools are not without a guiding educational concept. The concept of education in a modern public school can be defined, according to Medveš (1991), with three characteristics in terms of the relationship between a child's upbringing and the educational function: (1) the primacy of educational function before upbringing, (2) education as a preparation for coexistence and not as an improvement, and (3) the primacy of the educational process before the product. The school, of course, performs an essential educational function, but no educational concept or doctrine can be the basis for the legitimacy of a school's 'violence' against the child. 'Violence' here means a certain degree of coercion, which is always present at school (at least initially). The only aim of school education is to prepare its pupils for a life of complete diversity, to contribute to the correction of chaos and anarchy, to teach us to deal with conflicts in dealing with diversity, to teach us empathy and train us to anticipate the consequences of our own behaviour. It is a preparation for a rationally sound coexistence with others and nature. The common basis from which this education for life is derived is human rights. According to Medveš (1991), a plural school must be based on the principle of the universality of the educational effect on an individual. The universality of education is based on the simple fact that each individual must prepare for a life of diversity as a living possibility (ibid.). The author also writes that, in educational terms, the product (factual knowledge, estimates, tracking socially accepted behavioural patterns) becomes more important than the process, and therefore the school's educational quality must be measured more in terms of what people know and not what and how they learned. For the educational perspective, the opposite is true. The process becomes more important than the product; the quality of educational work in school can no longer depend on 'education' as a result outside of school, but on the form of the educational process itself. The teacher must, therefore, be aware that the quality of education is reflected directly in the relationships that he or she develops with the pupils. In principle, this means that the learning process, which takes place with regard to respecting diversity and tolerance, has already reached the goal of education. The establishment of such an educational process in the classroom is, in this case, the aim of education.

When planning and designing an educational concept or design (plan) for a public school, it is necessary to realise that every educational practice has its educational effects. There are many educational factors within the school that can be integrated into the whole with an educational concept. Educational concepts ${ }^{2}$ (Kroflič, 2004; Medveš,

2 The word 'concept' according to the Dictionary of Slovene Literary Language (2007) means "a composition, usually written, which is not yet complete or something that mediates the way in which it operates, events in some field," which rather summarises the author's findings. According to the Slovene Linguistic Language Dictionary (2007), a concept is "an initial, incomplete form of things". A plan, according to the Dictionary of Slovene Literary Language (2007), "is something 
2007; Gomboc, 2007; Berčnik, Devjak, 2016) through which schools express the strategies of their educational activities contain normative documents, goals, values, views, educational activities, educational measures, community rules, and frames of cooperation with parents. They should be designed at the level of a particular school. The educational design of Kovač Šebart (2007) is similar to the educational concept, which is a reflection (something unfinished) of the school's educational strategy, that includes formal rules, norms, the authority of the teacher, school culture, cooperation with parents and the wider community, concealed curriculum, and specific educational strategies.

\section{Impact of social changes on the change in the socialisation of children and youth, and risk factors for the emergence of violence from an etiological perspective}

With social changes, the 'social integration paradigm' (Zorc Maver, 2007, 147) of the socialisation of children and adolescents is also changing. This was once done in a linear sequence of predictable status transitions, which is no longer valid for today's youth. Lifestyles are becoming more and more individualised, which in turn means that the young must rely more on themselves than other social collective forms. Today's youth is increasingly exposed to decisions about their future, for which they must also take full responsibility. This means there is a need for an increase in care that is especially important for young people from deprivileged environments. Increased fragmentation, uncertainty and individualisation cause many problems, distress and fractures in the lives of young people.

The paradigm of 'controlling life' is becoming the dominant model for the socialisation of children and adolescents. The concept of managing life requirements applies not only to young people's problems, but also to changes in the biographical situation of young people as a whole. "The more socio-integrative institutions disappear, the more young people in the society are directly exposed" (Zorc Maver, 2007, 146). Social structural changes in youth thus mark on the one hand a greater possibility for young people to individually shape and plan their own lives, and on the other, the pluralism of lifestyles brings with it increasing risks. There is a growing danger that goals and desires cannot be achieved, which leads to many disappointments. Failure in this way can lead to an unhealthy feeling to which individuals can be very sensitive. More possibilities for self-experimentation and greater individualistic self-

that predetermines the way, the place, the time in which the act is to be successfully implemented, something that anyone intends to realise, including a draft, a proposal". 
examination possibilities also imply greater demands in the field of mental and social competences for managing everyday life.

The traditional concept of identities envisaged stable social contexts and predictable courses of life for young people. However, the process of identity formation has become unstable and undermined by many fractures, in which an individual has to establish their identity over and over again; the modern individual is free from the control and security that occur with traditional ties and family, the system of religion and morals, and becomes the designer and organiser of their own social relations and life course (Beck, 1986; Zorc Maver, 2007). Social changes have many impacts on the socialisation of children and adolescents. Despite greater freedom in the socio-cultural field, as well as greater participation and pluralisation of lifestyles, the material dependence of young people has now been extended to the third decade of their lives. The conditions for enrolling in certain educational programmes have been exacerbated, and even though graduation and/or certification have become indispensable conditions for employment, they do not provide employment. All these contradictions create new uncertainties in the period of adolescence and many burdens for young people, when planning of the future is very uncertain. School negligence represents a serious hinderance to the individual being able to choose their desired school and thus a certain professional field. This is because school success greatly influences the professional planning and realisation of an individual's life goals. The related burdens and problems can lead to various psychosocial and health issues (Hurrelmann, 1986).

The school, as a social institution, controls social and psychological factors that trigger deviant forms of behaviour, and thus also violence. The reason is that a school assumes a socially effective definition and categorisation of productivity, success and failure that no other institution dealing with children and adolescents has (Hurrelmann, 1986; Mansel, Hurrelmann, 1991). Categorising pupils as 'poor at learning, and 'unsuccessful' leads to a reduction in the sense of self-worth and worse employment opportunities in the future. Violence can thus be understood as a compensatory mechanism in relation to the psychological and social uncertainties that occur in school, and in this sense the school itself is the cause of deviant acts and violence (Rutter, Maugham, Mortimer, Ousten, 1980).

The terms 'deviant behaviour' and 'violence' have many definitions. Cohen (1968) wrote that the deviant behaviour of an individual always refers to the existence of some rules and is related to some behaviour, and such definitions are directed exclusively to violations of norms, the fulfilment or failure of which produces a positive or negative form of social control. According to this view, the "violence of an individual is treated 
as a form of unwanted behaviour that occurs in the context of a school" (Milivojević, 2010, 11). Another theory of deviation was given by Durkheim with his thesis of anomie (Lamnek, 1994), stating that "anomie is a social state in which collective consciousness is weakened; the objectives of action are vague because socially anchored moral beliefs are weakened" (ibid. 18). Merton (1968) explained the phenomenon of social disintegration with the theory of anomie, simultaneously linking deviant and conformal behaviour. According to his theory, "deviant behaviour occurs when an individual is in a critical life situation in which his own operating resources are abandoned, insufficient or overloaded, the ability to function is compromised and an individual attempts to restore his ability to act through deviant behaviour". According to Zorc Maver (2007), when there are discrepancies in the relationship between the social structure and the institutional structure of expectations, individuals attempt to adapt to the anomic structure with various forms of behaviour, ranging from conformity to deviance. Socially acceptable behaviour can be expected when work and norms are balanced, or an equilibrium can be expected in those adolescents who have a wide range of control strategies based on their family environment and sociocultural resources. When there are discrepancies in the relationship between the social structure and the institutional structure of expectations, or where individuals have a narrow repertoire of control strategies and little or no protection system, individuals attempt to adapt to an anomalous structure with different forms of behaviour. Lamnek (1994) wrote that deviation is not only a characteristic of an (unacceptable) action, but a product of social interactions that produces deviation in institutional contexts and, in defining behavioural defects, the perception and reaction of the environment to disturbing behaviour are crucial (ibid).

Such critical life experiences, which, as a rule, are perceived by the individual as a major loss of self-worth, produce feelings of impotence, which the individual projects onto other weak peers, so that he or she is able to function and restore balance (Gruen, 1992). We cannot overlook the fact that children coming from socially deprived environments have much greater possibility for school failure than those from privileged environments (Cooper, Barnbara, 2012). There is a strong link between learning failure and social, emotional, and behavioural problems, and such problems and social deprivation. In contrast, the school reflects various structural options on which it has no influence. The onset of violence is thus conditioned by external factors, which the school cannot change. As such, despite achieving learning success it is not guaranteed that these young people will be able to realise their employment and occupational ambitions.

Based on research (Mansel, Hurrelmann, 1991; Spreiter, 1993), risk factors for the occurrence of violence can include, inter alia, inadequate family relationships. 
Hurelmann (1986) confirms the notion that inappropriate family relationships, deprivation, poverty, separation and inadequate educational style can contribute to the emergence of aggressive behaviour. Family change research highlights the increased burden that today's families are exposed to with regard to providing a sufficient material existence, or the need for parents to develop themselves, which leads some to not meet the basic needs of their children (Hensel, 1993). Disobedience, fear and, isolation are signs that a child is lacking in protective and orientation systems, which can have negative consequences for their development. Distance from school norms and values, distance from school, and the denial of school norms and values also represent significant factors in predicting aggressiveness in school. Absence from school and failure to meet school obligations can lead to a negative attitude towards school. Joining delinquent groups is a sign that an individual seeks to satisfy their needs among others following deviations from norms. Among the factors behind the increased risk of violence are school failure, a poor school climate, and bad relations between teachers and pupils. School failure causes reduced employment opportunities for the individual and contributes to distancing of the pupil from the school, and seeking connections with delinquent groups. Research shows (Cooper, Barnbara, 2012) that all the factors that contribute to the poor self-evaluation of an individual and poorer opportunities in later life are significant factors for the risk of aggressive behaviour in school. A school climate in which there are no clear criteria with regard to the consequences of certain behaviour leads to greater anomalies at the school, which can represent a risk factor for the occurrence of violence. In contrast, relations between teachers and pupils based on democratic principles and the greater participation of adolescents in school contribute to the positive personality development of the individual.

\section{Preventive discipline in response to the educational problems of today's schools}

Various authors dealing with authority, discipline or educational activities at school (Kroflič, 2002; Pšunder, Dečman Dobrnjič, 2010; Lenič, Devjak, 2010) find that establishing positive relationships in the pedagogical process is crucial for achieving success in education. In establishing preventive discipline, we see an opportunity to improve the current situation in elementary schools. To achieve good results, we need to work consistently and at the same time at several levels: with the individual, their family, the class and the school they are attending, and the wider local community in which they live. ${ }^{3}$ Meško (2000) sees prevention as a method of working with

3 The beginnings of preventive discipline date back to the middle of the $19^{\text {th }}$ century, when in an industrial suburb of Turin, don Bosco founded an educational institution for youth, where the 
young people, especially with groups at risk; It is about teaching and raising a child through experiencing thins (i.e., an experiential pedagogy ${ }^{4}$ ). The preventive aspect is understood by the author as learning the skills and practices needed for life, learning about the world and, in a safe way, experiencing adventures that would not allow young people to come into conflict with norms, either informal rules or formal laws (Lenič, Devjak, 2010). Among the features of the preventive system we also consider dialogic (this is a pedagogical conversation in which co-responsibility develops) and frequent praise that encourages permanent personal growth in individuals. Different authors perceive preventive discipline differently, but many common points can be found among them. Pšunder (2004) combines various aspects of preventive discipline into three main areas of preventive action. The first fundamental area of preventive action speaks of the establishment of a pleasant, relaxed and, above all, stimulating class climate, based on positive interpersonal relationships between teachers and pupils, among peers, and between teachers and parents. The second area of preventive action references the teacher's preparations for teaching and teaching itself; it is about successful teaching with the help of appropriate learning methods that involve and motivate pupils for instruction, while also taking into account their psychological and learning needs. The third core area of preventive action is broader, and is linked to activities related to the organisation, running, and management of the class; this area has to be regulated at the beginning of the school year, while actively involving pupils, thereby encouraging their responsibility for their own behaviour. It is mainly planning the class and school rules and procedures, and clearly stating the consequences that follow their violation, planning strategies to prevent potential disciplinary problems, and planning those for stopping and dealing with problems that have already arisen (ibid.).

Bear's (1998) model of preventive discipline in school is based on a good classroom climate, knowledge of an individual, taking into account the opinions, wishes and interests of the individual, and stimulating the participation of pupils. The teacher not only strives to teach social behaviour and reduce unwanted behaviour, but also helps pupils to develop knowledge and emotions associated with social behaviour; takes into account and respects the diversity of pupils, emphasises honesty, prevents competition and social comparisons, uses co-operative learning activities, avoids creating feelings of shame (more focus on pride and less guilt), and supports acts of affection in school

Salesians developed an education system whose basic characteristic was preventive education. Through his educational methods, means. and behaviour, he attempted to prevent the occurrence of unwanted educational effects.

4 Experiential pedagogy is a young pedagogical discipline that can be described as a party after a long time of denial and helplessness; it is a departure from modern technology, communication devices that enable us to be all the time available; it is the withdrawal to our own body, nature in all its innocence (Krajnčan, 2007). 
and community, often communicating with the parents and being concerned with regard to providing positive feedback, incentives and praise, as well as giving clear rules early in the school year. The feedback given by such teachers is characterised by being sincere and credible. Chalvin (2004) says that a positive critique, which is characterised by being oriented towards the future and being open, clear and simple, is also good to improve behaviour. He marks it as valuable information that causes a change and attempts to improve school relationships.

Even for those rules that apply in elementary school, it is essential that they are clear and represent reasonable expectations. Bear (ibid.) lists the basic characteristics of the rules and understands them as requirements and prohibitions concerning class behaviour. Edwards (1997) and Rogers (1998) argue that preventive discipline deals primarily with fundamental rights and clear rules and consequences, agreed with pupils, with class arrangement and curriculum design. Among the elements of preventive discipline, they include clear rules and standards designed with the class; clear expectations of learning and tasks; an attractive environment; a good classroom arrangement; a dedicated the space for rest; suitable areas of work and organising a curriculum that meets different abilities. According to Jones and Jones (2001), effective preventative discipline is based on the teacher's understanding of class management and the pupils' personal, psychological, and learning needs. They propose working in three key areas: 1) interpersonal relations, which involve the creation of positive relationships between pupils and teachers, peers and cooperation with parents; 2) motivation and teaching taking into account pupils learning needs; and 3) management and organisation with methods that support pupils' appropriate behaviour.

The teacher should use as many positive statements as possible in their interactions with pupils. Negative criticisms can have a very bad influence on pupil's behaviour and encourage resistance to school, and often violence is a response of young people to such pressure (Managing misbehaviour in schools, 1993). It is also important for the teacher to express positive expectations regarding the work of pupils in the classroom and to promote the attainment of the set goals. For good relations, it is also necessary to create opportunities for personal discussions with all pupils; with this, the teacher expresses their interest in activities that are important to the individual. A good interpersonal relationship also contributes to an environment in which pupils feel safe and accepted. The teacher should express their concern about pupils' achievements and behaviour with professional, open and encouraging dialogue, active listening and incentives, by being ready to look at and reveal the pupils' good sides, stimulating their thinking and appreciating their opinions, and looking for opportunities to contact each individual in class. Through the implementation of many activities, pupils become better acquainted with each other, thus improving the class climate and consequently 
reducing the number of disciplinary problems. We also know about activities for creating related, supportive groups and activities that promote mutual acceptance and good relations among peers (Lenič, Devjak, 2010) ${ }^{5}$.

The complexity of factors that contribute to deviant, aggressive or even violent behaviour suggests that the problem of discipline is multidimensional, and therefore does not have easy, quick solutions (Cowie, Dawn, 2007). Awareness and recognition of the risks faced by pupils is the first step towards solving the problem. Schools promote various proactive and preventive strategies, including the learning of constructive conflict resolution and helping pupils to face problems in a peaceful way, such as restitution, peer mediation and the use of a children's parliament (Verbnik Dobnikar, 2007). To successfully carry out a preventive programme at elementary school, however, it is important that teachers, counsellors, school leaders, pupils, their families, peer groups and the local community are acquainted with changeoriented strategies. A stimulating environment is an essential factor in supporting and maintaining a preventive programme at school; success is the result of constructive cooperation at all these levels (Bemak, Keys, 2003).

\section{Conclusion}

Good interpersonal relationships between pupils, teachers, counsellors, and school leadership are crucial for the successful functioning of each school,- and thus are the essence of a positive school climate. True pedagogical discipline is thus conscious self-discipline, which begins with education in the family and continues at school. In the understanding of discipline, many things can be done before we encounter conflict, trouble, and problems. Theoretical concepts in the field of deviant behaviour and prevention, new methodical approaches for promoting an appropriate culture of living at school, working with parents, teachers and the wider local community, are the path to a cooperative culture at school. One of the more successful approaches to preventive discipline is to give pupils the responsibility for setting rules, of course within certain limits. With this, we show the pupils that we trust and accept them as partners in the community. This is one of the main guides of experiential pedagogy. With the introduction of experiential pedagogy to school, we would also avoid possible

5 Certain theoretical concepts of prevention at school were studied in Slovenia as part of a research project entitled The Partnership of Faculties and Schools, Model 3, financed by the European Social Fund and the Ministry of Education and Sport in the years 2006-2007. With the help of the research, a 24 hour program of in-service teacher training and education for all professional staff of the school for the identification of educational issues was developed, evaluated, carried out in order to carry out preventive forms and methods of work in the process of education and training of school staff, to design such forms and methods of work that enable pupils and students to actively participate in solving common forms of life and work and coexistence, at school and in the social environment where they live (Devjak et al., 2007). 
stigmatisation, which we know to have significant consequences for young people; at the same time, this method would be of great help in preventive or supportive work with young people. Systematic preventive programs of social and emotional learning provide students with an understanding of their emotions, appropriate conflict resolution, responsible decision making, and increased self-esteem, and should pay more attention to them in the future. Given today's social changes, school remains an essential place for the socialisation of adolescents, as it opens new related interactions, extends identification patterns, and assists individuals in integrated learning, thereby contributing to the strengthening of young people's individual and social resources, and thus to the more successful management of (non-violent) life.

\section{References}

Beck, U., Risikogeselschaft. Auf dem Weg in eine andere Moderne, Frankfurt a. M. 1986.

Berčnik, S., Devjak, T., Zgodovinski diskurz sodelovanja med šolo in starši v Sloveniji, Pedagoška obzorja = Didactica Slovenica, revija za didaktiko in metodiko 1, 2016, pp. 3-14.

Bear, G. G., School discipline in the United States: Prevention, correction, and longterm social development, School Psychology Review 27, 1989, pp. 14-32.

Bemak, F., Keys, S., Violent and Aggressive Youth - Intervention and Prevention, Strategies for Changing Times, Practical Skills for Counselors, Thousand Oaks 2000.

Chalvin, M. J., Kako preprečiti konflikte, Radovljica 2004.

Charles, C. M., Buliding classroom discipline, New York 1996.

Cowie, H., Dawn, J., Managing Violence in Schools - A Whole-school Approach to Best Practice, London 2007.

Cooper, P., Barnbara, J., From Inclusion to engagement, Oxford 2012.

Devjak, T. et al., Pravila in vzgojno delovanje šole: teoretična izhodišča in empirični podatki, in: Pravila in vzgojno delovanje šole (ed. Devjak, T.), Ljubljana 2007, pp. 17-100.

Devjak, T., Pedagogika - poglavja iz teorije vzgoje, študijsko gradivo, Ljubljana 2017.

Edwards, C. H., Classroom discipline and management, New Jersey 1997.

Galtung, J., Strukturelle Gewalt, Beiträge zur Friedens- und Konfliktforschung, Reinbeck bei Hamburg 1975.

Gomboc, M., Izhodišča za oblikovanje vzgojnega koncepta osnovne šole in vzgojnih načrtov osnovnih šol, Sodobna pedagogika, posebna izdaja, 2007, pp. 196-209.

Gruen, A., Der Verrat am Selbst, München 1992. 
Hensel, R., Auf dem Weg zu weniger Gewalt - auch durch das Leben in der Schule, in: Wafenstillstand im Klassenzimmer (ed. Spreiter, M.), Weinheim 1993, pp. 167.

Hurrelmann, K., Einführung in die Sozialisationstheorie, Weinheim 1986.

Jones, V. F., Jones, L. S., Comprehensive classroom management: creating communities of support and solving problems, Boston 2001.

Kovač Šebart, M., Krek, J., Vogrinc, J., O vzgojni zasnovi v javnih osnovnih šolah - kaj pokažejo empirični podatki. Sodobna pedagogika 5, 2006, pp. 22-44.

Kovač Šebart, M. et. al., The role and educational activities in partnership schools, in: Living together, XIII World congress of comparative education societies, Sarajevo 2007, p. 171.

Krajnčan, M., Osnove doživljajske pedagogike, Ljubljana 2007.

Kroflič, R., Učiteljeva zaveza vzgojnim ciljem šole, Sodobna pedagogika, posebna izdaja, 2004, pp. 76-88.

Kroflič, R., Tudi šole vzgajajo, mar ne? in: Pravila in vzgojno delovanje šole (ed. Devjak, T.), Ljubljana 2007, pp. 101-118.

Lamnek, S., Neue Theorien Abweichenden Verhaltens, München 1994.

Lenič, K., Devjak, T., Preventivna disciplina v socialni in doživljajski pedagogiki - na ravni posameznika, družine, oddelka, šole in lokalne skupnosti, Ljubljana 2010.

Managing Misbehaviour in Schools, Second edition, London, New York 1993.

Mansel, J., Hurrelmann, K., Alltagsstress bei Jugendlichen, München 1991.

Medveš, Z., Pedagoška etika in koncept vzgoje. 1. in 2. del. Sodobna pedagogika 3-4 and 5-6, 1991, pp. 101-117 and pp. 214-226.

Medveš, Z., Vzgojni koncept na razpotjih sodobnosti, ugotovitve in predlogi mednarodne znanstvene konference, Sodobna pedagogika 2, 2007, pp. 227-232.

Merton, R. K., Sozialstruktur und Anomie, in: Kriminalsoziologie (ed. Koenig R., Sack, F.), Frankfurt a. M. 1974, pp. 283-313.

Meško, G., Razmišljanje o doživljajski pedagogiki kot metodi neformalnega družbenega nadzorstva, in: Zbornik 1. slovenskega kongresa doživljajske pedagogike z mednarodno udeležbo, Ljubljana 2000, pp. 13-18.

Milharčič, M., Državljanska vzgoja?, Časopis za kritiko znanosti 172/173, 1994, pp. 55-66.

Milivojević, Z., Pomembnost čustev za preprečevanje nasilja v šoli, in: Znanje o čustvih za manj nasilja $v$ šoli (ed. Muršič, M.), Ljubljana 2010, pp. 11-13.

Pavlovič, Z., Je vzgoja v (javni) šoli legitimna? Kakšna vzgoja?, Sodobna pedagogika, 1, 2000, pp. 178-186. 
Počkar, M., Šolske ideologije in družbena neenakost, magistrska naloga, Ljubljana 1997.

Pšunder, H. M., Disciplina v sodobni šoli, Ljubljana 2004.

Pšunder, M., Dečman Dobrnjič, O., Alternativni vzgojni ukrepi med teorijo, zakonodajo in prakso, Ljubljana 2010.

Rogers, E. W., Wright, P. M., Measuring organizational performance in strategic human resource management: Problems and prospects, Ithaca, NY 1998.

Rutter, M. et. al., Funfzehntausend Stunden. Schulen und ihre Wirkung auf Kinder, Weinheim, Basel 1980.

Slovar slovenskega knjižnega jezika, http://bos.zrc-sazu.si/sskj.html [25. 2. 2018].

Spreiter, M., Wafenstillstand im Klassenzimmer, Weinheim 1993.

Verbnik Dobnikar, T., Vrstniška mediacija v šoli, in: Pravila in vzgojno delovanje šole (ed. Devjak, T.), Ljubljana 2007, pp. 187-203.

Zakon o osnovni šoli, Ljubljana 1996.

Zakon o spremembah in dopolnitvah Zakona o osnovni šoli, Ljubljana 2007.

Zaviršek, D., Diskurzi o nasilju in pomoči, Socialno delo 5/6, 1997, pp. 329-345.

Zgaga, P., Današnje možnosti praktične filozofije, Anthropos 1/3, 1991, pp. 98-102.

Zorc Maver, D., Otroci s težavami v socialni integraciji, in: Pravila in vzgojno delovanje šole (ed. Devjak, T.), Ljubljana 2007, pp. 142-151. 
Tatjana Devjak, Darja Zorc Maver

\section{Otrokove pravice in preventivno vzgojno delovanje $v$ javni osnovni šoli kot odgovor na nasilje in odklonsko vedenje}

Ključne besede: otrokove pravice, vzgojna zasnova, javna šola, neprimerno vedenje, preventivne dejavnosti

Avtorici v prispevku analizirata pomen vzgojne zasnove in preventivnega vzgojnega delovanja $\mathrm{v}$ osnovni šoli ter utemeljujeta potrebo po sistematičnem načrtovanju, izvajanju, spremljanju in evalviranju vzgojne dejavnosti v javni osnovni šoli. Izhajata iz predpostavke, da družbene spremembe vplivajo tudi na spremembe $\mathrm{v}$ socializaciji otrok in mladine. Izpostavita kompleksnost dejavnikov, ki prispevajo $\mathrm{k}$ neprimernemu, agresivnemu ali nasilnemu vedenju. Prikažeta teorije anomije, interakcionistične teorije kot osnove za analizo odklonskega vedenja in predstavita preventivno disciplino kot odgovor na vzgojne težave, nasilje in odklonsko vedenje $\mathrm{v}$ javni osnovni šoli. 
Tatjana Devjak, Darja Zorc Maver

\section{Child Rights and Preventive Educational Activities in Public Elementary Schools in Response to Violence and Deviant Behaviour}

Keywords: child rights, educational concept, public school, deviant behaviour, preventive activities

In this paper, the authors analyse the importance of educational concepts and preventive education in elementary school, and support the need for the systematic planning, implementation, monitoring, and evaluation of educational activities in public primary schools. This assumes that social changes also affect changes in the socialisation of children and youth. The authors reveal the complexity of factors that contribute to deviant, aggressive, or violent behaviour, discuss theories of anomie and interaction theory as the basis for the analysis of deviant behaviour, and present preventive discipline in response to educational problems, violence, and deviant behaviour in public elementary schools. 